Article

\title{
Biodiesel Production from a Novel Nonedible Feedstock, Soursop (Annona muricata L.) Seed Oil
}

\author{
Chia-Hung Su*, Hoang Chinh Nguyen, Uyen Khanh Pham, My Linh Nguyen and Horng-Yi Juan \\ Graduate School of Biochemical Engineering, Ming Chi University of Technology, New Taipei City 24301, \\ Taiwan; d10522811@mail.ntust.edu.tw (H.C.N.); d913612@alumni.nthu.edu.tw (U.K.P.); \\ m07138213@mail2.mcut.edu.tw (M.L.N.), hyjuan@mail.mcut.edu.tw (H.-Y.J.) \\ * Correspondence: chsu@mail.mcut.edu.tw; Tel.: +886-22-908-9899 (ext. 4665)
}

Received: 11 August 2018; Accepted: 24 September 2018; Published: 26 September 2018

\begin{abstract}
This study investigated the optimal reaction conditions for biodiesel production from soursop (Annona muricata) seeds. A high oil yield of $29.6 \%(w / w)$ could be obtained from soursop seeds. Oil extracted from soursop seeds was then converted into biodiesel through two-step transesterification process. A highest biodiesel yield of $97.02 \%$ was achieved under optimal acid-catalyzed esterification conditions (temperature: $65{ }^{\circ} \mathrm{C}, 1 \% \mathrm{H}_{2} \mathrm{SO}_{4}$, reaction time: $90 \mathrm{~min}$, and a methanol:oil molar ratio: 10:1) and optimal alkali-catalyzed transesterification conditions (temperature: $65{ }^{\circ} \mathrm{C}$, reaction time: $30 \mathrm{~min}, 0.6 \% \mathrm{NaOH}$, and a methanol:oil molar ratio: 8:1). The properties of soursop biodiesel were determined and most were found to meet the European standard EN 14214 and American Society for Testing and Materials standard D6751. This study suggests that soursop seed oil is a promising biodiesel feedstock and that soursop biodiesel is a viable alternative to petrodiesel.
\end{abstract}

Keywords: Annona muricata; biodiesel production; seed oil; soursop; two-step process

\section{Introduction}

Fossil fuel depletion and environmental concerns have stimulated the search for alternative fuels from renewable sources. Biodiesel, a biomass-derived fuel, is renewable, exhibits superior combustion properties, and is completely suitable for diesel engines [1,2]. Furthermore, the use of biodiesel results in relatively low environmental pollution because biodiesel is sulfur free and emits minimal carbon monoxide and hydrocarbons [3-5]. Because of these merits, biodiesel has been developed worldwide to replace petrodiesel.

Biodiesel has been mainly produced from edible oil using an acid, alkali, or enzyme catalyst $[6,7]$. Nevertheless, the use of edible oil as a feedstock increases the production cost of biodiesel [8], thus limiting the commercialization of biodiesel. Furthermore, the use of edible feedstock for fuel purpose may cause adverse effects on food supply [9-11]; therefore, alternative feedstocks must be identified for biodiesel synthesis. Numerous cheap and nonedible feedstocks, including microalgae oil [12-14], Jatropha oil [15,16], waste cooking oil [17-19], insect fat [20-22], Chinese tallow tree seed oil [23], tobacco seed oil [24], sweet basil seed oil [25], Brucea javanica seed oil [26], spent coffee grounds [27], and food waste [28] have been investigated as vital feedstocks for biodiesel synthesis. Two-step transesterification (acid-catalyzed esterification followed by alkali-catalyzed transesterification) is a promising method to produce biodiesel from high free fatty acid oils [29,30]. The acid oils (fatty acid content $>1 \%, w / w)$ should be esterified using an acid catalyst to lower the oil acidity before applying an alkali catalyst to transesterify the oil into biodiesel [31-33]. This two-step process not only minimizes soap formation but also enhances biodiesel yield [31,34,35]. 
Soursop (Annona muricata L.), which belongs to the Annonaceae family, is an economically critical crop worldwide [36,37]. A. muricata is native to North and South America and is popularly distributed in the tropical and subtropical areas of Western Africa, Central America, the Caribbean, and the Asian continent [37-39]. The A. muricata tree is approximately 5-8-m tall with low branches [39], and the trees yield up to 10 tons of fruit per hectare [38]. The oval or heart-shaped fruit is $15-30-\mathrm{cm}$ in length, 10-20-cm in width, and, on average, weighs up to $4.0 \mathrm{~kg}[36,39]$. The edible white pulp of soursop fruit comprises about $80 \%$ water, $18 \%$ carbohydrate, $1 \%$ protein, and $1 \%$ fiber content and contains beneficial vitamins [40]. The mesocarp contains numerous black seeds, which are each approximately $2 \mathrm{~cm}$ long and $1 \mathrm{~cm}$ wide [36]. The soursop is mainly cultivated for its fruit, which is used in fresh and processed forms in the production of juice, ice cream, sherbet, beverages, and candy [37,41,42]. The use of soursop fruit in food production results in various waste materials, including seeds which account for $5-8.5 \%$ of the fruit $[37,38,43]$. The seeds are usually discarded and cannot be used as animal feed because they contain toxic substances such as annonacin and acetogenins [37,43,44]. Studies have shown that oil comprises up to $40 \%$ of the soursop seed [37]. The seed oil mainly comprises palmitic acid, oleic acid, and linoleic acid [37,45]. This composition is similar to that of other biodiesel feedstocks $[24,29,31]$. Therefore, the nonedible soursop seed oil is a promising and cheap biodiesel feedstock. In addition, the use of this seed for biodiesel synthesis can resolve the problematic surplus of the seed in the food industry. Only few studies have reported the potential use of this seed oil for biodiesel production [46,47]. However, no optimization study on reaction conditions has investigated for biodiesel production from $A$. muricata seed oil.

This study optimized the reaction factors for producing biodiesel from A. muricata seed oil. Because of the presence of a high level of free fatty acid (FFA) in the seed oil, a two-step process was used to convert FFAs and triglycerides into biodiesel. The effects of reaction factors (molar ratio of methanol to oil, temperature, catalyst amount, and reaction time) on esterification and transesterification were investigated to optimize the reaction conditions. The biodiesel's properties were finally characterized according to the American Society for Testing and Materials (ASTM) methods.

\section{Materials and Methods}

\subsection{Materials}

Ripe soursop fruits were purchased from Thu Duc Agromarket (Ho Chi Minh City, Vietnam). The seeds were removed from the fruit and air-dried at room temperature for 3 days. The soursop seed kernels were then separated from the hulls, ground with a blender (EUPA TSK-935BAP, Tsann Kuen Enterprise Co., Ltd., Taipei, Taiwan), and stored at room temperature. Methanol, sulfuric acid, sodium hydroxide, $n$-hexane, and other reagents used in this study were of analytical grade ( $\geq 99.0 \%$ purity) and were obtained from Tedia Company, Inc. (Fairfield, CT, USA).

\subsection{Extraction of Crude Oil}

Soursop seed powder was immersed in n-hexane $(1: 4, w / v)$ at room temperature for 2 days, and stirred to extract the oil from soursop seed. After extraction, the hexane layer was separated from solid residue by filtration (Advantec No. 5C filter paper). The n-hexane was then removed using a R300 Buchi Rotary Evaporator (Büchi Labortechnik, Flawil, Switzerland), and the soursop seed crude oil was obtained. The crude oil's properties, such as acidity, saponification, and iodine values, were measured using the standard method [48,49]. 


\subsection{Production of Biodiesel through Two-Step Process}

\subsubsection{Esterification Step}

An $\mathrm{H}_{2} \mathrm{SO}_{4}$-catalyzed pretreatment was employed to reduce the oil's acidity and convert its FFAs into biodiesel. To study the influence of reaction factors on esterification, several experimental trials were conducted in a sealed reactor with stirring under different conditions: molar ratios of methanol to oil (4:1-12:1), temperatures $\left(45-85^{\circ} \mathrm{C}\right)$, catalyst amounts $(0.25-2.0 \%)$, and reaction times $(30-150 \mathrm{~min})$. After each reaction, the samples were withdrawn to evaluate the FFA conversion.

\subsubsection{Transesterification Step}

The oil pretreated through $\mathrm{H}_{2} \mathrm{SO}_{4}$-catalyzed esterification was used for the transesterification step. The esterified reaction mixture was kept in a funnel for phase separation. After two phases were completely separated, the crude oil and biodiesel (upper layer) was poured into a sealed reactor and subsequently transesterified into biodiesel using $\mathrm{NaOH}$ as catalyst. A set of experiments with various methanol to oil molar ratios $(4: 1-12: 1)$, temperatures $\left(45-85^{\circ} \mathrm{C}\right)$, catalyst amounts $(0.4-1.2 \%)$, and reaction times (15-75 $\mathrm{min}$ ) were studied for their effects on the conversion yield. After each reaction, the reactor was placed at room temperature for phase separation. The mixture's upper layer containing biodiesel was collected to determine the biodiesel yield.

\subsection{Analysis}

The acid value (AV) of the oil sample was measured using a titration method reported previously [50,51]. The FFA conversion was then calculated as follows:

$$
\text { FFA conversion }(\%)=\frac{\mathrm{AV}_{1}-\mathrm{AV}_{2}}{\mathrm{AV}_{1}} \times 100
$$

where $A V_{1}$ is the initial acid value, and $A V_{2}$ is the acid value after the esterification reaction.

The composition of the biodiesel was quantified using a Shimadzu GC-2014 gas chromatograph system (Shimadzu Corp., Kyoto, Japan) equipped with a Stabilwax capillary column (Restek Corp., Bellefonte, PA, USA) and a flame ionization detector (Shimadzu Corp., Kyoto, Japan) according to the procedure reported in our previous study [10]. The fatty acid profiles of the soursop biodiesel were characterized based on Supelco 37 Component FAME Mix reference standards (Sigma-Aldrich Corp., St. Louis, MO, USA). The biodiesel content was quantified by comparing the peak areas of fatty acid methyl esters with those of the internal standard, methyl pentadecanoate. The soursop biodiesel yield was then calculated as follows [10]:

$$
\text { Biodiesel yield }(\%)=\frac{A_{\text {sample }}}{A_{\text {standard }}} \times \frac{W_{\text {standard }}}{W_{\text {sample }}} \times \frac{W_{\text {biodiesel }}}{W_{\text {oil }}} \times 100
$$

where $A_{\text {sample }}$ is peak area of biodiesel sample, $A_{\text {standard }}$ is peak area of international standard, $W_{\text {sample }}$ is weigh of biodiesel sample, $W_{\text {standard }}$ is weight of internal standard, $W_{\text {biodiesel }}$ is weight of total biodiesel product, and $W_{\text {oil }}$ is weight of oil used.

The acid value, viscosity, sulfur content, water content, ester content, cetane index, density, and flash point of the produced biodiesel were determined using the ASTM D664, D445, D5453, D95, D7371, D613, D1480, and D93 methods, respectively [52].

\section{Results and Discussion}

\subsection{Properties of Soursop Seed Oil}

Table 1 shows the characteristics of soursop seed oil. The oil extracted from soursop seeds reached the yield of $29.6 \%$, demonstrating the soursop seed's high oil content and subsequent potential as 
an oil source. The saponification value of soursop seed oil was $244.7 \mathrm{mg} \mathrm{KOH} / \mathrm{g}$, indicating that the average molecular weight of soursop seed oil was $884.4 \mathrm{~g} / \mathrm{mol}$. The acid value of the soursop seed oil was $54.4 \mathrm{mg} \mathrm{KOH} / \mathrm{g}$, indicating a high FFA content. Biodiesel production processes must be refined to maximize the value of materials and minimize costs $[25,53,54]$. To maximize the biodiesel yield from oils with high FFA levels, esterification must be performed to reduce the level of FFAs prior to transesterification $[31,34,35]$. Therefore, the two-step process of acid-catalyzed esterification followed by alkali-transesterification was selected for biodiesel synthesis from soursop seed oil in this study.

Table 1. Properties of crude soursop seed oil.

\begin{tabular}{ccc}
\hline Fat Yield (\%) & Acid Value (mg KOH/g) & Saponification Value $(\mathbf{m g ~ K O H} / \mathbf{g})$ \\
\hline $29.6 \pm 0.2$ & $54.4 \pm 0.4$ & $244.7 \pm 1.6$ \\
\hline
\end{tabular}

\subsection{Conversion of FFAs into Biodiesel through Acid-Catalyzed Esterification}

\subsubsection{Effect of Methanol to Oil Molar Ratio}

Esterification pretreatment enhances the biodiesel yield by reducing the oil's acidity and converting its FFAs into biodiesel $[29,51]$. To optimize reaction conditions, this study investigates the influences of methanol to oil molar ratio, temperature, $\mathrm{H}_{2} \mathrm{SO}_{4}$ amount, and reaction time on the FFAs conversion. First, esterification was performed at $75{ }^{\circ} \mathrm{C}$ with $1 \% \mathrm{H}_{2} \mathrm{SO}_{4}(w / w)$ and various methanol to oil molar ratios (4:1-12:1) for $60 \mathrm{~min}$. As shown in Figure 1a, FFA conversion was greater at higher methanol to oil molar ratios. This result corresponds with those of other studies [35,55]. The molar ratio of methanol to oil is a critical factor affecting the efficiency of esterification reactions. A high methanol to oil molar ratio is required to drive esterification reactions toward completion [55]. In this work, the highest FFA conversion occurred at the methanol:oil molar ratio of 12:1. However, the FFA conversion had insignificant differences between the methanol:oil molar ratios of 12:1 and 10:1. Therefore, the methanol:oil molar ratio of 10:1 was chosen for the next experiments.
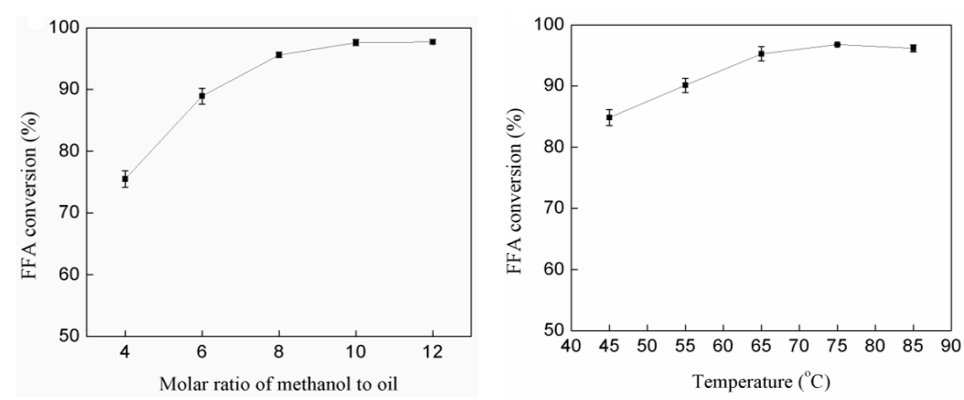

(a)

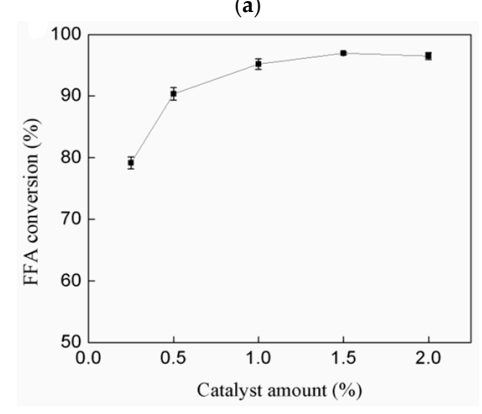

(c)

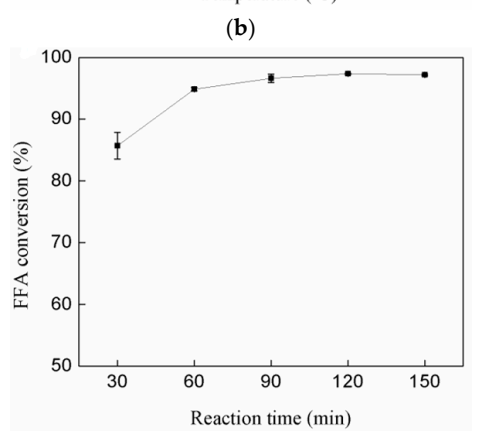

(d)

Figure 1. Effects of (a) molar ratio of methanol to oil (with a fixed temperature of $75{ }^{\circ} \mathrm{C}, 1 \% \mathrm{H}_{2} \mathrm{SO}_{4}$, and a reaction time of $60 \mathrm{~min}$ ); (b) temperature (with a fixed methanol:oil molar ratio of 10:1, $1 \% \mathrm{H}_{2} \mathrm{SO}_{4}$, and a reaction time of $60 \mathrm{~min}$ ); (c) catalyst amount (with a fixed methanol:oil molar ratio of 10:1, a temperature of $65{ }^{\circ} \mathrm{C}$, and a reaction time of $60 \mathrm{~min}$ ); and (d) reaction time (with a fixed methanol:oil molar ratio of 10:1, a temperature of $65^{\circ} \mathrm{C}$, and $1 \% \mathrm{H}_{2} \mathrm{SO}_{4}$ ) on FFA conversion in soursop seed oil. 


\subsubsection{Effect of Temperature}

To investigate the impact of temperature on the efficiency of esterification, the reaction was performed at various temperatures $\left(45-85^{\circ} \mathrm{C}\right)$, whilst keeping the other factors constant. As shown in Figure 1b, FFA conversion was enhanced from 84.86 to $96.16 \%$ when the temperature was increased from 45 to $85^{\circ} \mathrm{C}$. This result is reasonable because a high temperature enhances the reaction rate $[51,56]$. However, no significant differences were found in the proportion of FFA conversion at temperatures of 65,75 , and $85{ }^{\circ} \mathrm{C}$. Therefore, to reduce energy consumption, $65^{\circ} \mathrm{C}$ was selected as the optimal temperature for the esterification reaction.

\subsubsection{Effect of Catalyst Amount}

The results in Figure 1c reflect the effect of sulfuric acid amount on FFA conversion. FFA conversion significantly improved when the catalyst levels increased from 0.25 to $1.0 \%$. Nevertheless, increasing the catalyst load to $1.5 \%$ resulted in only a slight increase in FFA conversion, and a $2 \%$ catalyst load caused a slight decrease in conversion efficiency. This slight decrease at a $2 \%$ catalyst load is similar to of the results of other studies [35,55]. Excess $\mathrm{H}_{2} \mathrm{SO}_{4}$ catalyst can activate the polymerization of unsaturated FFA, causing the product's darkened color due to the oxidation and decarboxylation of FFA [55]. Therefore, $1.0 \% \mathrm{H}_{2} \mathrm{SO}_{4}$ was chosen as the optimal catalyst amount for further experiments.

\subsubsection{Effect of Reaction Time}

Various reaction times (30-150 $\mathrm{min}$ ) were tested for esterification performed at $65{ }^{\circ} \mathrm{C}$ with a methanol:oil molar ratio of 10:1 and $1 \% \mathrm{H}_{2} \mathrm{SO}_{4}(w / w)$. As shown in Figure $1 \mathrm{~d}$, FFA conversion increased from 85.71 to $96.61 \%$ when increasing reaction time from 30 to $90 \mathrm{~min}$. Increases in reaction times beyond $90 \mathrm{~min}$ resulted in insignificant increases in FFA conversion, indicating that reactions reached equilibrium at $90 \mathrm{~min}$. In conclusion, the optimal conditions for the $\mathrm{H}_{2} \mathrm{SO}_{4}$-catalyzed esterification were determined to be a methanol:oil molar ratio: $10: 1$, a temperature: $65^{\circ} \mathrm{C}, 1 \% \mathrm{H}_{2} \mathrm{SO}_{4}(w / w)$, and $90 \mathrm{~min}$. These conditions were thus used in this study for the esterification step in biodiesel production.

\subsection{Conversion of Triglyceride into Biodiesel through Alkali-Catalyzed Transesterification}

\subsubsection{Effect of Methanol to Oil Molar Ratio}

The esterified oil was used as the material for producing biodiesel through alkali-catalyzed transesterification. To optimize transesterification conditions, the influences of methanol to oil molar ratio, temperature, $\mathrm{NaOH}$ amount, and reaction time on the biodiesel yield were examined. First, transesterification was performed at $65{ }^{\circ} \mathrm{C}$ with $0.8 \% \mathrm{NaOH}(w / w)$ and various methanol to oil molar ratios (4:1-12:1) for $30 \mathrm{~min}$. As can be seen from Figure 2a, the biodiesel yield increased from $81 \%$ to $96.37 \%$ when the molar ratio of methanol to oil was increased from $4: 1$ to $8: 1$. Nevertheless, a higher methanol to oil molar ratio caused a decrease in the biodiesel yield. This result is consistent with that reported in the study of biodiesel synthesis from Jatropha curcus seed oil [31] and Croton megalocarpus oil [57]. A high level of methanol may have increased the glycerol solubility in the solution, driving the equilibrium to a reverse reaction and thus lowering the biodiesel yield [57]. Therefore, this study selected the methanol:oil molar ratio of 8:1 as the optimal reactant ratio for transesterification. 


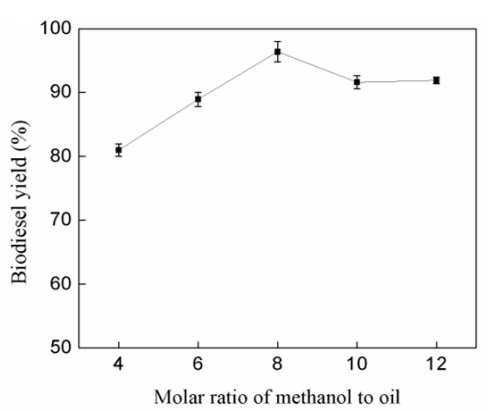

(a)

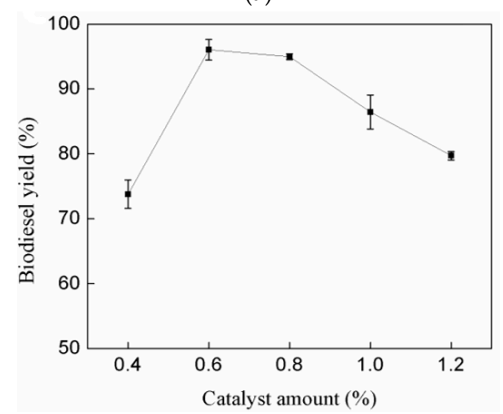

(c)

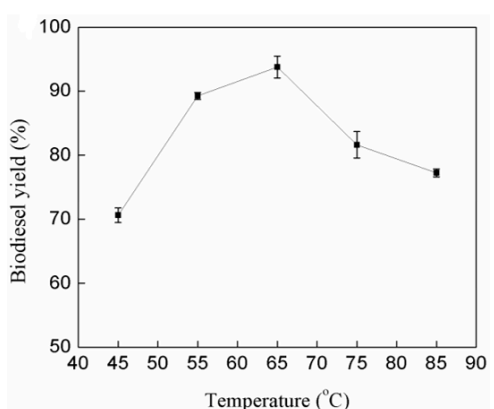

(b)

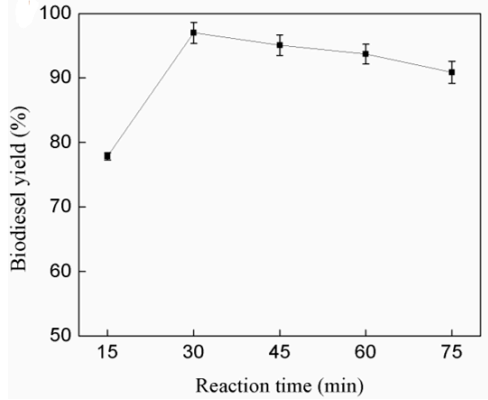

(d)

Figure 2. Effects of (a) molar ratio of methanol to oil (with a fixed temperature of $65{ }^{\circ} \mathrm{C}, 0.8 \% \mathrm{NaOH}$, and a reaction time of $30 \mathrm{~min}$ ); (b) temperature (with a fixed methanol:oil molar ratio of 8:1, 0.8\% $\mathrm{NaOH}$, and a reaction time of $30 \mathrm{~min}$ ); (c) catalyst amount (with a fixed methanol:oil molar ratio of 8:1, a temperature of $65{ }^{\circ} \mathrm{C}$, and a reaction time of $30 \mathrm{~min}$ ); and (d) reaction time (with a fixed methanol:oil molar ratio of $8: 1$, a temperature of $65^{\circ} \mathrm{C}$, and $0.6 \% \mathrm{NaOH}$ ) on transesterification of soursop seed oil.

\subsubsection{Effect of Temperature}

To investigate the influence of temperature on the biodiesel yield, transesterification was carried out at various temperatures $\left(45-85^{\circ} \mathrm{C}\right)$ with a methanol to oil molar ratio, $\mathrm{NaOH}$ amount, and reaction time maintained at $8: 1,0.8 \%$, and $30 \mathrm{~min}$, respectively. As can be seen from Figure $2 \mathrm{~b}$, the biodiesel yield increased when temperature was increased from 45 to $65^{\circ} \mathrm{C}$. Nevertheless, the biodiesel yield reduced at temperatures greater than $65^{\circ} \mathrm{C}$. This result is in agreement with those of other studies $[57,58]$. A high temperature may have enhanced side reactions, including saponification, thus resulting in a lower biodiesel yield [57]. Based on this result, $65^{\circ} \mathrm{C}$ was chosen as the optimal temperature for the transesterification.

\subsubsection{Effect of Catalyst Amount}

Catalyst amount is a critical factor affecting the efficiency of transesterification. In this study, various $\mathrm{NaOH}$ amounts were tested with other factors maintained as constant to evaluate the influence of $\mathrm{NaOH}$ amount on the biodiesel yield. Results revealed that the biodiesel yield increased when the amount of catalyst increased from 0.4 to $0.6 \%$ (Figure 2c). However, when the catalyst amount is higher than $0.6 \%$, the biodiesel yield reduced. Excess catalyst favored the saponification reaction, enhancing the formation of an emulsion and gel, thus lowering the biodiesel yield $[31,55,57]$. Therefore, $0.6 \%$ $\mathrm{NaOH}$ was selected for use in further experiments. 


\subsubsection{Effect of Reaction Time}

Finally, the influence of reaction time on the biodiesel yield was examined using the optimal reaction conditions obtained in previous experiments. Transesterification was performed at $65{ }^{\circ} \mathrm{C}$ with a methanol:oil molar ratio of $8: 1,0.6 \% \mathrm{NaOH}(w / w)$, and various reaction times $(15-75 \mathrm{~min})$. As indicated in Figure 2d, the biodiesel yield increased from 77.85 to $97.02 \%$ when the reaction time increased from 15 to $30 \mathrm{~min}$. A reaction time longer than $30 \mathrm{~min}$ caused a slight decrease in the biodiesel yield. Therefore, a reaction time of $30 \mathrm{~min}$ was determined as sufficient for the transesterification reaction. In conclusion, the highest biodiesel yield of $97.02 \%$ was achieved under the following optimal transesterification conditions: $65^{\circ} \mathrm{C}, 0.6 \% \mathrm{NaOH}(w / w), 30 \mathrm{~min}$, and methanol:oil molar ratio of 8:1.

\subsection{Fatty Acid Profiles of Soursop Biodiesel}

Table 2 illustrates the fatty acid profiles of soursop biodiesel in comparison with rapeseed biodiesel. Nine fatty acid methyl esters were identified in the soursop biodiesel, among which oleic acid methyl ester $(43.68 \%)$, linoleic acid methyl ester $(32.45 \%)$, and palmitic acid methyl ester $(18.14 \%)$ were present in the highest amounts. The synthesized biodiesel was found to comprise $78.07 \%$ unsaturated fatty acids and $21.93 \%$ saturated ones. The saturated fatty acid level in soursop biodiesel was higher than that of rapeseed biodiesel (4.3\%) [51], indicating a higher cetane index for the soursop biodiesel. This is because the high level of saturated fatty acid increases the cetane index of a fuel [59]. In addition, because saturated fatty acid methyl esters exhibit higher oxidative stability than unsaturated ones $[4,60]$, the soursop biodiesel can have more oxidative stability than rapeseed biodiesel. These results suggest that soursop seed oil is a suitable feedstock for biodiesel synthesis.

Table 2. Fatty acid methyl ester compositions of soursop biodiesel compared with rapeseed biodiesel.

\begin{tabular}{|c|c|c|}
\hline Composition & Rapeseed Biodiesel ${ }^{a}(\%)$ & Soursop Biodiesel ${ }^{b}(\%)$ \\
\hline Palmitic acid methyl ester (C16:0) & 3.5 & 18.14 \\
\hline Palmitoleic acid methyl ester (C16:1) & $\mathrm{na}^{\mathrm{c}}$ & 0.81 \\
\hline Stearic acid methyl ester (18:0) & 0.8 & 3.79 \\
\hline Oleic acid methyl ester (C18:1) & 64.4 & 43.68 \\
\hline Linoleic acid methyl ester (C18:2) & 22.3 & 32.45 \\
\hline Linolenic acid methyl ester (C18:3) & 8.2 & 1.13 \\
\hline
\end{tabular}

${ }^{\mathrm{a}}$ Data obtained from Reference $[51] ;{ }^{\mathrm{b}}$ This study; ${ }^{\mathrm{c}}$ na $=$ none reported.

\subsection{Properties of Soursop Biodiesel}

The soursop biodiesel's properties were characterized using ASTM standard methods and were compared with the corresponding properties of rapeseed biodiesel [51]. As indicated in Table 3, most soursop biodiesel's properties were similar to those of rapeseed biodiesel. Remarkably, most properties of synthesized biodiesel, sulfur content $(0.04 \%)$, ester content $(98.6 \%)$, viscosity $\left(5.5 \mathrm{~mm}^{2} / \mathrm{s}\right)$, water content $(300 \mathrm{mg} / \mathrm{kg})$, cetane number $(53)$, density $\left(868 \mathrm{~kg} / \mathrm{m}^{3}\right)$, and flash point $\left(123^{\circ} \mathrm{C}\right)$, met the standards ASTM D6751 [52] and EN 14,214 [61]. These results indicate that the synthesized biodiesel may serve as an alternative to petrodiesel. Moreover, the high ester content in the biodiesel indicates that the conditions identified in this study are optimal for the esterification and transesterification reactions. However, the acid value of synthesized biodiesel was 0.8 , which was higher than the standards EN 14,214 and ASTM D6751: this could be due to the presence of free fatty acid in the biodiesel product. A further purification step is therefore required in order to reduce the acid value [62]. 
Table 3. Soursop biodiesel's properties compared with those of rapeseed biodiesel, the standards ASTM D6751, and EN 14214.

\begin{tabular}{|c|c|c|c|c|c|}
\hline Properties & $\begin{array}{l}\text { ASTM } \\
\text { Method }\end{array}$ & $\begin{array}{c}\text { ASTM } \\
\text { D6751 }^{a}\end{array}$ & EN 14214 & $\begin{array}{c}\text { Rapeseed } \\
\text { Biodiesel }^{b}\end{array}$ & This Study \\
\hline Acid value (mg $\mathrm{KOH} / \mathrm{g}$ ) & D664 & $<0.5$ & $<0.5$ & 0.31 & $<0.8$ \\
\hline Sulfur content (wt. \%) & D5453 & $<0.05$ & $<0.05$ & $<0.01$ & 0.04 \\
\hline Ester content $(\%)$ & D7371 & $\mathrm{na}^{\mathrm{c}}$ & $>96.5$ & $\mathrm{na}^{\mathrm{c}}$ & 98.6 \\
\hline Viscosity at $40^{\circ} \mathrm{C}\left(\mathrm{mm}^{2} / \mathrm{s}\right)$ & D445 & $1.9-6.0$ & $3.5-5.0$ & 6.35 & 5.5 \\
\hline Water content $(\mathrm{mg} / \mathrm{kg})$ & D95 & $\mathrm{na}^{\mathrm{c}}$ & $<500$ & 300 & 300 \\
\hline Cetane number & D613 & $>47$ & $>51$ & 45 & 53 \\
\hline Density $\left(\mathrm{kg} / \mathrm{m}^{3}\right)$ & D1480 & $\mathrm{na}^{\mathrm{c}}$ & $860-900$ & 880 & 868 \\
\hline Flash point (closed cup) $\left({ }^{\circ} \mathrm{C}\right)$ & D93 & $100-170$ & $>120$ & $\mathrm{na}^{\mathrm{c}}$ & 123 \\
\hline
\end{tabular}

${ }^{\mathrm{a}}$ Data obtained from Reference [52]; ${ }^{\mathrm{b}}$ Data were obtained from Reference [51]; ${ }^{\mathrm{c}}$ na $=$ none reported.

\subsection{The Feasibility of Soursop Seed Oil as Biodiesel Feedstock}

With an increasing demand for renewable energy, biodiesel has been widely produced to replace petrodiesel. To reduce the production cost, various non-edible feedstocks including microbial oil [12-14], waste cooking oil [17-19], insect fat [20-22], and plant seed oil [23-25], have been studied for biodiesel production because of their low-price. However, the availability of those oils is still a major concern for large-scale production [10]. Therefore, efforts have been made to search for new low-cost biodiesel feedstocks. In recent years, the use of plant seed obtained from fruit production industry for biodiesel production has attracted much attention due to its low cost and availability $[25,26]$. In the state of Bahia (Brazil), approximately 20 thousand tons of soursop fruit are produced annually, thus producing about 1.7 thousand tons of soursop seed each year [37]. Since soursop is an economically important crop worldwide [37,41], the global food production from soursop fruit can cause a problematic surplus of this seed. To add value to the soursop seeds, the effective method of recycling these seeds is being investigated. In the present study, soursop seeds were used as a non-edible feedstock for biodiesel production-a solution to the soursop seed disposal problem. The results suggested that soursop seed can be a potential biodiesel feedstock along with other non-edible plant seed oils.

\section{Conclusions}

This paper investigates the use of soursop seed oil for biodiesel production. In the current study, the reaction conditions of acid-catalyzed esterification and alkali-catalyzed transesterification were optimized to maximize biodiesel yield. Under optimized conditions, 97.02\% biodiesel yield was obtained. The properties of the soursop biodiesel were determined and were found to meet the ASTM D6751 and EN 14214. The results of this study suggest that soursop seed oil is a potential biodiesel feedstock and the soursop biodiesel can serve as an alternative for petrodiesel.

Author Contributions: Conceptualization, C.-H.S. and H.C.N.; methodology, C.-H.S. and H.C.N.; validation, H.-J.Y. and U.K.P.; formal analysis, U.K.P and M.L.N.; investigation, U.K.P. and M.L.N; resources, C.-H.S.; writing - original draft preparation, C.-H.S. and H.C.N.; writing-review and editing, C.-H.S.; supervision, C.-H.S.; project administration, C.-H.S.; funding acquisition, C.-H.S.

Funding: This research was funded by Ministry of Science and Technology (MOST) of Taiwan, grant number 106-2221-E-131-028.

Conflicts of Interest: The authors declare no conflicts of interest.

\section{References}

1. Mosarof, M.; Kalam, M.; Masjuki, H.; Alabdulkarem, A.; Ashraful, A.; Arslan, A.; Rashedul, H.; Monirul, I. Optimization of performance, emission, friction and wear characteristics of palm and Calophyllum inophyllum biodiesel blends. Energy Convers. Manag. 2016, 118, 119-134. [CrossRef] 
2. Damanik, N.; Ong, H.C.; Tong, C.W.; Mahlia, T.M.I.; Silitonga, A.S. A review on the engine performance and exhaust emission characteristics of diesel engines fueled with biodiesel blends. Environ. Sci. Pollut. Res. 2018, 25, 15307-15325. [CrossRef] [PubMed]

3. Anwar, M.; Rasul, M.G.; Ashwath, N. Production optimization and quality assessment of papaya (Carica papaya) biodiesel with response surface methodology. Energy Convers. Manag. 2018, 156, 103-112. [CrossRef]

4. Knothe, G. “Designer” biodiesel: Optimizing fatty ester composition to improve fuel properties. Energy Fuels 2008, 22, 1358-1364. [CrossRef]

5. Abdul Malik, M.S.; Shaiful, A.I.M.; Mohd Ismail, M.S.; Mohd Jaafar, M.N.; Mohamad Sahar, A. Combustion and emission characteristics of coconut-based biodiesel in a liquid fuel burner. Energies 2017, 10, 458. [CrossRef]

6. Leung, D.Y.; Wu, X.; Leung, M. A review on biodiesel production using catalyzed transesterification. Appl. Energy 2010, 87, 1083-1095. [CrossRef]

7. Bhuyan, M.S.U.S.; Alam, A.H.M.A.; Chu, Y.; Seo, Y.C. Biodiesel production potential from littered edible oil fraction using directly synthesized $\mathrm{S}-\mathrm{TiO}_{2} / \mathrm{MCM}-41$ catalyst in esterification process via non-catalytic subcritical hydrolysis. Energies 2017, 10, 1290. [CrossRef]

8. Mardhiah, H.H.; Ong, H.C.; Masjuki, H.; Lim, S.; Lee, H. A review on latest developments and future prospects of heterogeneous catalyst in biodiesel production from non-edible oils. Renew. Sustain. Energy Rev. 2017, 67, 1225-1236. [CrossRef]

9. Martindale, W.; Trewavas, A. Fuelling the 9 billion. Nat. Biotechnol. 2008, 26, 1068-1070. [CrossRef] [PubMed]

10. Nguyen, H.C.; Liang, S.H.; Doan, T.T.; Su, C.H.; Yang, P.C. Lipase-catalyzed synthesis of biodiesel from black soldier fly (Hermetica illucens): Optimization by using response surface methodology. Energy Convers. Manag. 2017, 145, 335-342. [CrossRef]

11. Tuntiwiwattanapun, N.; Monono, E.; Wiesenborn, D.; Tongcumpou, C. In-situ transesterification process for biodiesel production using spent coffee grounds from the instant coffee industry. Ind. Crops Prod. 2017, 102, 23-31. [CrossRef]

12. El Shimi, H.I.; Moustafa, S.S. Biodiesel production from microalgae grown on domestic wastewater: Feasibility and Egyptian case study. Renew. Sustain. Energy Rev. 2018, 82, 4238-4244. [CrossRef]

13. Chia, S.R.; Ong, H.C.; Chew, K.W.; Show, P.L.; Phang, S.M.; Ling, T.C.; Nagarajan, D.; Lee, D.J.; Chang, J.S. Sustainable approaches for algae utilisation in bioenergy production. Renew. Energy 2018, 129, 838-852. [CrossRef]

14. Ghorbani, A.; Rahimpour, M.R.; Ghasemi, Y.; Raeissi, S. The biodiesel of microalgae as a solution for diesel demand in Iran. Energies 2018, 11, 950. [CrossRef]

15. Kamel, D.A.; Farag, H.A.; Amin, N.K.; Zatout, A.A.; Ali, R.M. Smart utilization of jatropha (Jatropha curcas Linnaeus) seeds for biodiesel production: Optimization and mechanism. Ind. Crops Prod. 2018, 111, 407-413. [CrossRef]

16. Lin, J.J.; Chen, Y.W. Production of biodiesel by transesterification of Jatropha oil with microwave heating. J. Taiwan Inst. Chem. Eng. 2017, 75, 43-50. [CrossRef]

17. Milano, J.; Ong, H.C.; Masjuki, H.H.; Silitonga, A.S.; Chen, W.H.; Kusumo, F.; Dharma, S.; Sebayang, A.H. Optimization of biodiesel production by microwave irradiation-assisted transesterification for waste cooking oil-Calophyllum inophyllum oil via response surface methodology. Energy Convers. Manag. 2018, 158, 400-415. [CrossRef]

18. Hossain, M.N.; Siddik Bhuyan, M.S.U.; Alam, A.H.M.A.; Seo, Y.C. Biodiesel from hydrolyzed waste cooking oil using a S-ZrO 2 /SBA-15 super acid catalyst under sub-critical conditions. Energies 2018, 11, 299. [CrossRef]

19. Poudel, J.; Karki, S.; Sanjel, N.; Shah, M.; Oh, S.C. Comparison of biodiesel obtained from virgin cooking oil and waste cooking oil using supercritical and catalytic transesterification. Energies 2017, 10, 546. [CrossRef]

20. Nguyen, H.C.; Liang, S.H.; Chen, S.S.; Su, C.H.; Lin, J.H.; Chien, C.C. Enzymatic production of biodiesel from insect fat using methyl acetate as an acyl acceptor: Optimization by using response surface methodology. Energy Convers. Manag. 2018, 158, 168-175. [CrossRef]

21. Zheng, L.; Hou, Y.; Li, W.; Yang, S.; Li, Q.; Yu, Z. Exploring the potential of grease from yellow mealworm beetle (Tenebrio molitor) as a novel biodiesel feedstock. Appl. Energy 2013, 101, 618-621. [CrossRef]

22. Surendra, K.; Olivier, R.; Tomberlin, J.K.; Jha, R.; Khanal, S.K. Bioconversion of organic wastes into biodiesel and animal feed via insect farming. Renew. Energy 2016, 98, 197-202. [CrossRef] 
23. Barekati-Goudarzi, M.; Muley, P.D.; Clarens, A.; Nde, D.B.; Boldor, D. Continuous microwave-assisted in-situ transesterification of lipids in seeds of invasive Chinese tallow trees (Triadica sebifera L.): Kinetic and thermodynamic studies. Biomass Bioenergy 2017, 107, 353-360. [CrossRef]

24. García-Martínez, N.; Andreo-Martínez, P.; Quesada-Medina, J.; de los Ríos, A.P.; Chica, A.; Beneito-Ruiz, R.; Carratalá-Abril, J. Optimization of non-catalytic transesterification of tobacco (Nicotiana tabacum) seed oil using supercritical methanol to biodiesel production. Energy Convers. Manag. 2017, 131, 99-108. [CrossRef]

25. Amini, Z.; Ong, H.C.; Harrison, M.D.; Kusumo, F.; Mazaheri, H.; Ilham, Z. Biodiesel production by lipase-catalyzed transesterification of Ocimum basilicum L. (sweet basil) seed oil. Energy Convers. Manag. 2017, 132, 82-90. [CrossRef]

26. Hasni, K.; Ilham, Z.; Dharma, S.; Varman, M. Optimization of biodiesel production from Brucea javanica seeds oil as novel non-edible feedstock using response surface methodology. Energy Convers. Manag. 2017, 149, 392-400. [CrossRef]

27. Tuntiwiwattanapun, N.; Tongcumpou, C. Sequential extraction and reactive extraction processing of spent coffee grounds: An alternative approach for pretreatment of biodiesel feedstocks and biodiesel production. Ind. Crops Prod. 2018, 117, 359-365. [CrossRef]

28. Sakuragi, K.; Li, P.; Otaka, M.; Makino, H. Recovery of bio-oil from industrial food waste by liquefied dimethyl ether for biodiesel production. Energies 2016, 9, 106. [CrossRef]

29. Chen, L.; Liu, T.; Zhang, W.; Chen, X.; Wang, J. Biodiesel production from algae oil high in free fatty acids by two-step catalytic conversion. Bioresour. Technol. 2012, 111, 208-214. [CrossRef] [PubMed]

30. Silva, L.N.; Cardoso, C.C.; Pasa, V.M. Production of cold-flow quality biodiesel from high-acidity on-edible oils-Esterification and transesterification of Macauba (Acrocomia aculeata) oil using various alcohols. BioEnergy Res. 2016, 9, 864-873. [CrossRef]

31. Berchmans, H.J.; Hirata, S. Biodiesel production from crude Jatropha curcas L. seed oil with a high content of free fatty acids. Bioresour. Technol. 2008, 99, 1716-1721. [CrossRef] [PubMed]

32. Suresh, R.; Antony, J.V.; Vengalil, R.; Kochimoolayil, G.E.; Joseph, R. Esterification of free fatty acids in non-edible oils using partially sulfonated polystyrene for biodiesel feedstock. Ind. Crops Prod. 2017, 95, 66-74. [CrossRef]

33. Nguyen, H.C.; Huong, D.T.M.; Juan, H.Y.; Su, C.H.; Chien, C.C. Liquid lipase-catalyzed esterification of oleic acid with methanol for biodiesel production in the presence of superabsorbent polymer: Optimization by using response surface methodology. Energies 2018, 11, 1085. [CrossRef]

34. Çaylı, G.; Küsefoğlu, S. Increased yields in biodiesel production from used cooking oils by a two step process: Comparison with one step process by using TGA. Fuel Process. Technol. 2008, 89, 118-122. [CrossRef]

35. Hayyan, A.; Alam, M.Z.; Mirghani, M.E.; Kabbashi, N.A.; Hakimi, N.I.N.M.; Siran, Y.M.; Tahiruddin, S. Reduction of high content of free fatty acid in sludge palm oil via acid catalyst for biodiesel production. Fuel Process. Technol. 2011, 92, 920-924. [CrossRef]

36. Coria-Téllez, A.V.; Montalvo-Gónzalez, E.; Yahia, E.M.; Obledo-Vázquez, E.N. Annona muricata: A comprehensive review on its traditional medicinal uses, phytochemicals, pharmacological activities, mechanisms of action and toxicity. Arab. J. Chem. 2016, 11, 662-691. [CrossRef]

37. Schroeder, P.; do Nascimento, B.P.; Romeiro, G.A.; Figueiredo, M.K.K.; da Cunha Veloso, M.C. Chemical and physical analysis of the liquid fractions from soursop seed cake obtained using slow pyrolysis conditions. J. Anal. Appl. Pyrolysis 2017, 124, 161-174. [CrossRef]

38. Fasakin, A.; Fehintola, E.; Obijole, O.; Oseni, O. Compositional analyses of the seed of sour sop, Annona muricata L., as a potential animal feed supplement. Sci. Res. Essays 2008, 3, 521-523.

39. Moghadamtousi, S.Z.; Fadaeinasab, M.; Nikzad, S.; Mohan, G.; Ali, H.M.; Kadir, H.A. Annona muricata (Annonaceae): A review of its traditional uses, isolated acetogenins and biological activities. Int. J. Mol. Sci. 2015, 16, 15625-15658. [CrossRef] [PubMed]

40. de Lima, M.C.; Alves, R. Soursop (Annona muricata L.). In Postharvest Biology and Technology of Tropical and Subtropical Fruits: Mangosteen to White Sapote; Yahia, E., Ed.; Woodhead Publishing: Cambridge, UK, 2011; pp. 363-392.

41. Gajalakshmi, S.; Vijayalakshmi, S.; Devi Rajeswari, V. Phytochemical and pharmacological properties of Annona muricata: A review. Int. J. Pharm. Pharm. Sci. 2012, 4, 3-6.

42. Awan, J.; Kar, A.; Udoudoh, P. Preliminary studies on the seeds of Annona muricata Linn. Plant Foods Hum. Nutr. 1980, 30, 163-168. [CrossRef] 
43. Badrie, N.; Schauss, A.G. Soursop (Annona muricata L.): Composition, nutritional value, medicinal uses, and toxicology. In Bioactive Foods in Promoting Health; Watson, R.R., Preedy, V.R., Eds.; Academic Press: Oxford, UK, 2010; pp. 621-643.

44. Zafra-Polo, M.C.; González, M.C.; Estornell, E.; Sahpaz, S.; Cortes, D. Acetogenins from Annonaceae, inhibitors of mitochondrial complex I. Phytochemistry 1996, 42, 253-271. [CrossRef]

45. Elagbar, Z.A.; Naik, R.R.; Shakya, A.K.; Bardaweel, S.K. Fatty acids analysis, antioxidant and biological activity of fixed oil of Annona muricata L. seeds. J. Chem. 2016, 6. [CrossRef]

46. Phoo, Z.W.M.M.; Ilham, Z.; Goembira, F.; Razon, L.; Saka, S. Physico-chemical properties of biodiesel from various feedstocks. In Zero-Carbon Energy Kyoto 2012; Yao, T., Ed.; Springer: Berlin, Germany, 2013; pp. 113-121.

47. Schroeder, P.; dos Santos Barreto, M.; Romeiro, G.A.; Figueiredo, M.K.K. Development of energetic alternatives to use of waste of Annona muricata L. Waste Biomass Valorization 2018, 9, 1459-1467. [CrossRef]

48. Su, C.H.; Fu, C.C.; Gomes, J.; Chu, I.; Wu, W.T. A heterogeneous acid-catalyzed process for biodiesel production from enzyme hydrolyzed fatty acids. AIChE J. 2008, 54, 327-336. [CrossRef]

49. Vicente, G.; Martınez, M.; Aracil, J. Integrated biodiesel production: A comparison of different homogeneous catalysts systems. Bioresour. Technol. 2004, 92, 297-305. [CrossRef] [PubMed]

50. Su, C.H. Recoverable and reusable hydrochloric acid used as a homogeneous catalyst for biodiesel production. Appl. Energy 2013, 104, 503-509. [CrossRef]

51. Li, Q.; Zheng, L.; Cai, H.; Garza, E.; Yu, Z.; Zhou, S. From organic waste to biodiesel: Black soldier fly, Hermetia illucens, makes it feasible. Fuel 2011, 90, 1545-1548. [CrossRef]

52. Annual Book of ASTM Standards. Available online: https://www.astm.org/BOOKSTORE/BOS/index.html (accessed on 26 September 2018).

53. Ramadhas, A.; Jayaraj, S.; Muraleedharan, C. Characterization and effect of using rubber seed oil as fuel in the compression ignition engines. Renew. Energy 2005, 30, 795-803. [CrossRef]

54. Emil, A.; Yaakob, Z.; Kumar, M.S.; Jahim, J.M.; Salimon, J. Comparative evaluation of physicochemical properties of Jatropha seed oil from Malaysia, Indonesia and Thailand. J. Am. Oil Chem. Soc. 2010, 87, 689-695. [CrossRef]

55. Ramadhas, A.S.; Jayaraj, S.; Muraleedharan, C. Biodiesel production from high FFA rubber seed oil. Fuel 2005, 84, 335-340. [CrossRef]

56. Nguyen, H.C.; Liang, S.H.; Li, S.Y.; Su, C.H.; Chien, C.C.; Chen, Y.J.; Huong, D.T.M. Direct transesterification of black soldier fly larvae (Hermetia illucens) for biodiesel production. J. Taiwan Inst. Chem. Eng. 2018, 85, 165-169. [CrossRef]

57. Kafuku, G.; Mbarawa, M. Biodiesel production from Croton megalocarpus oil and its process optimization. Fuel 2010, 89, 2556-2560. [CrossRef]

58. Meng, X.; Chen, G.; Wang, Y. Biodiesel production from waste cooking oil via alkali catalyst and its engine test. Fuel Process. Technol. 2008, 89, 851-857. [CrossRef]

59. Yang, S.; Li, Q.; Gao, Y.; Zheng, L.; Liu, Z. Biodiesel production from swine manure via housefly larvae (Musca domestica L.). Renew. Energy 2014, 66, 222-227. [CrossRef]

60. Ramos, M.J.; Fernández, C.M.; Casas, A.; Rodríguez, L.; Pérez, Á. Influence of fatty acid composition of raw materials on biodiesel properties. Bioresour. Technol. 2009, 100, 261-268. [CrossRef] [PubMed]

61. Automotive Fuels-Fatty Acid Methyl Esters (FAME) for Diesel Engines-Requirements and Test Methods. Available online: http://agrifuelsqcs-i.com/attachments/1598/en14214.pdf (accessed on 25 September 2018).

62. Bala, V.S.S.; Thiruvengadaravi, K.V.; Kumar, P.S.; Premkumar, M.P.; Kumar, M.H.; Sivanesan, S. Removal of free fatty acids in Pongamia pinnata (Karanja) oil using divinylbenzene-styrene copolymer resins for biodiesel production. Biomass Bioenergy 2012, 37, 335-341. [CrossRef]

(C) 2018 by the authors. Licensee MDPI, Basel, Switzerland. This article is an open access article distributed under the terms and conditions of the Creative Commons Attribution (CC BY) license (http:// creativecommons.org/licenses/by/4.0/). 